Authors have nothing to disclose with regard to commercial support.

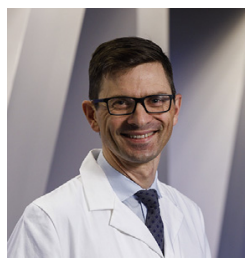

\section{EFFECTS OF BLOOD TRANSFUSIONS ON TRANSCATHETER AORTIC VALVE REPLACEMENT OUTCOMES}

\section{To the Editor:}

Kolte and colleagues ${ }^{1}$ report the results of a propensity score-matched study of hospitalizations for transcatheter aortic valve replacement in the National Inpatient Sample that matched hospitalizations with red blood cell (RBC) transfusions with hospitalizations without transfusions. They used International Classification of Diseases, Ninth Revision procedure codes to identify transfusions, and they cited $26.4 \%$ to $83 \%$ sensitivity and $97.5 \%$ to $100 \%$ specificity for these procedure codes.

Of the numbers provided for sensitivity, the high end $(83 \%)$ derives from a single-center case-control study of 716 records. $^{2}$ Other studies of varying sizes report much lower values, as described by Kolte and colleagues. ${ }^{1}$ A more recent study by Howard and colleagues, ${ }^{3}$ which validated billing records of 12,091 patients in 53 community hospitals, refined these numbers, describing $71.6 \%$ sensitivity and $92.6 \%$ specificity.

In addition, Kolte and colleagues ${ }^{1}$ identified a $17.3 \%$ transfusion rate in the transcatheter aortic valve replacement records from the National Inpatient Sample. Data from the Society of Thoracic Surgeons and American College of Cardiology Transcatheter Valve Therapy registry ${ }^{4}$ demonstrate an overall transfusion rate of $30.1 \%$ during the same period (2012-2015) studied by Kolte and colleagues. ${ }^{1}$ Together, these figures suggest a systemic undercoding of transfusions in the National Inpatient Sample, which introduces a substantial degree of unreliability into the process of propensity score matching.

Kolte and colleagues ${ }^{1}$ describe an undeniably important trend in the perioperative management of patients undergoing transcatheter aortic valve replacement: a decline in hospitalizations requiring $\mathrm{RBC}$ transfusion,

\footnotetext{
The Editor welcomes submissions for possible publication in the Letters to the Editor section that consist of commentary on an article published in the Journal or other relevant issues. Authors should: • Include no more than 500 words of text, three authors, and five references. • Type with double-spacing. • See http://jtcs.ctsnetjournals.org/ misc/ifora.shtml for detailed submission instructions. • Submit the letter electronically via jtcvs.editorialmanager.com. Letters commenting on an article published in the JTCVS will be considered if they are received within 6 weeks of the time the article was published. Authors of the article being commented on will be given an opportunity of offer a timely response ( 2 weeks) to the letter. Authors of letters will be notified that the letter has been received. Unpublished letters cannot be returned.
}

which is a worthy effort known to be associated with reduced complications and improved outcomes in cardiac surgery. ${ }^{5}$ Uncertainty regarding the validity of the International Classification of Diseases, Ninth Revision coding for RBC transfusion, however, highlights the potential weakness of administrative database use for clinical research into secondary procedures and diagnoses.

Clancy W. Mullan, MD

Matthew D. Pichert, MD

Arnar Geirsson, MD

Division of Cardiac Surgery

Department of Surgery

Yale University School of Medicine

New Haven, Conn

\section{References}

1. Kolte D, Beale C, Aronow HD, Kennedy KF, Apostolidou E, Sellke FW, et al Trends and outcomes of red blood cell transfusion in patients undergoing transcatheter aortic valve replacement in the United States. J Thorac Cardiovasc Surg. March 28, 2019 [Epub ahead of print].

2. Segal JB, Ness PM, Powe NR. Validating billing data for RBC transfusions: a brief report. Transfusion. 2001;41:530-3.

3. Howard DH, Karcz A, Roback JD. The accuracy of claims data for measuring transfusion rates. Transfus Med. 2016;26:457-9.

4. Grover FL, Vemulapalli S, Carroll JD, Edwards FH, Mack MJ, Thourani VH, et al STS/ACC TVT Registry. 2016 annual report of the Society of Thoracic Surgeons/ American College of Cardiology transcatheter valve therapy registry. J Am Coll Cardiol. 2017;69:1215-30

5. Yaffee DW, Smith DE III, Ursomanno PA, Hill FT, Galloway AC, DeAnda A, et al Management of blood transfusion in aortic valve surgery: impact of a blood conservation strategy. Ann Thorac Surg. 2014;97:95-101.

https://doi.org/10.1016/j.jtcvs.2019.05.070

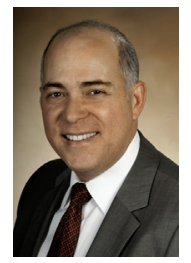

REPLY: ANALYSIS OF
ADMINISTRATIVE CLAIMS
DATA PROVIDES VALID AND
MEANINGFUL
CONCLUSIONS DESPITE ITS
IMPERFECTIONS
Reply to the Editor:

We thank Mullan and colleagues ${ }^{1}$ for their interest in our article. $^{2}$ They question the validity of the International Classification of Diseases, Ninth Edition, Clinical Modification (ICD-9-CM) procedure codes for red blood cell (RBC) transfusion and reference the study by Howard and associates, ${ }^{3}$ which demonstrated a sensitivity of $71.6 \% \quad(95 \%$ confidence interval, $60.4 \%-82.8 \%)$ and a specificity of $92.6 \%$ (95\% confidence interval, $88.3 \%-97.0 \%$ ) of ICD-9-CM codes for measuring transfusion. A key finding of that study, however, was that when 9 (out of 69) hospitals with claims-based transfusion rates of less than $10 \%$ were excluded, the sensitivity rates improved to $80.7 \% \quad(95 \%$ confidence interval, $74.4 \%-87.1 \%$ ). ${ }^{3}$ The modesty of the overall sensitivity of billing codes for transfusion is thus due to nonreporting or 
Authors have nothing to disclose with regard to commercial support.

underreporting by a small proportion of hospitals, rather than to "systemic undercoding of transfusions" as concluded by Mullan and colleagues. ${ }^{1}$ Although excluding hospitals with low transfusion rates may improve sensitivity, because there is substantial variability in transfusion rates across hospitals, doing so may result in loss of valid data. ${ }^{3,4}$

Further, the lower transfusion rates $(17.3 \%)$ in our study compared with those in the Society of Thoracic Surgeons and American College of Cardiology (STS/ACC) Transcatheter Valve Therapy (TVT) Registry (30.1\%) during the same period may also be due to important differences in the study populations. ${ }^{2,5}$ We excluded records of patients with RBC transfusion before the day of transcatheter aortic valve replacement (TAVR) and those for whom TAVR was not performed on day 0 or 1 of admission $\left(21.1 \%\right.$ of all TAVR procedures). ${ }^{2}$ The latter group likely includes hospitalized patients who underwent nonelective TAVR and were thus more likely to receive RBC transfusion. ${ }^{6}$ On the other hand, the STS/ACC TVT Registry does not include TAVR procedures performed as part of investigational device exemption trials, and previous studies have shown lower rates of transfusion in clinical trial populations. ${ }^{7,8}$

Finally, the results of our current study using the National Inpatient Sample (NIS) database ${ }^{2}$ are consistent with findings from a single-center study ${ }^{9}$ as well as the STS/ACC TVT Registry, ${ }^{10}$ both of which also demonstrated that RBC transfusion was associated with worse outcomes in patients undergoing TAVR. Thus, despite the modest sensitivity of $I C D-9-C M$ codes for RBC transfusion, we believe that the results of our propensity-matched analysis with the NIS database are reliable and provide important insights into the association between RBC transfusion and outcomes in patients undergoing TAVR. Prospective studies are needed to confirm our findings and to determine the utility of and optimal threshold for RBC transfusion in patients undergoing TAVR, especially among those with overt bleeding.

Dhaval Kolte, $M D, P h D^{a, b}$ Herbert D. Aronow, $M D, M P H^{a, b}$ Kevin F. Kennedy, $M S^{b}$ Afshin Ehsan, $M D^{a, b}$

${ }^{a}$ The Warren Alpert Medical School of Brown University Providence, RI

${ }^{b}$ Lifespan Cardiovascular Institute Providence, RI

\section{References}

1. Mullan CW, Pichert MD, Geirsson A. Effects of blood transfusions on transcatheter aortic valve replacement outcomes. J Thorac Cardiovasc Surg. 2019;158:e181-2.

2. Kolte D, Beale C, Aronow HD, Kennedy KF, Apostolidou E, Sellke FW, et al. Trends and outcomes of red blood cell transfusion in patients undergoing transcatheter aortic valve replacement in the United States. J Thorac Cardiovasc Surg. March 28, 2019 [Epub ahead of print].

3. Howard DH, Karcz A, Roback JD. The accuracy of claims data for measuring transfusion rates. Transfus Med. 2016;26:457-9.

4. McQuilten ZK, Andrianopoulos N, Wood EM, Cole-Sinclair MF, McNeil JJ, Cameron PA, et al. Transfusion practice varies widely in cardiac surgery: results from a national registry. J Thorac Cardiovasc Surg. 2014;147:1684-90.

5. Grover FL, Vemulapalli S, Carroll JD, Edwards FH, Mack MJ, Thourani VH, et al; STS/ACC TVT Registry. 2016 annual report of the Society of Thoracic Surgeons/American College of Cardiology transcatheter valve Therapy registry. J Am Coll Cardiol. 2017;69:1215-30.

6. Ando T, Adegbala O, Villablanca P, Akintoye E, Ashraf S, Shokr M, et al. Incidence, predictors, and in-hospital outcomes of transcatheter aortic valve implantation after nonelective admission in comparison with elective admission: from the nationwide inpatient sample database. Am J Cardiol. 2019;123:100-7.

7. Holmes DR Jr, Nishimura RA, Grover FL, Brindis RG, Carroll JD, Edwards FH, et al; STS/ACC TVT Registry. Annual outcomes with transcatheter valve therapy: from the STS/ACC TVT registry. J Am Coll Cardiol. 2015;66:2813-23.

8. Rao SV, Eikelboom JA, Granger CB, Harrington RA, Califf RM, Bassand JP. Bleeding and blood transfusion issues in patients with non-ST-segment elevation acute coronary syndromes. Eur Heart J. 2007;28:1193-204.

9. Apostolidou E, Aronow HD, Beale C, Kolte D, Kennedy KF, Sellke FW, et al. Association between red blood cell transfusion and clinical outcomes among patients undergoing transcatheter aortic valve replacement. Ann Thorac Surg. 2019;107:1791-8.

10. Sherwood MW, Xiang K, Matsouaka R, Vemulapalli S, Vora A, Peterson E, et al. Patterns of red blood cell transfusion and associated outcomes in patients undergoing TAVR: insights for the STS/ACC TVT registry. J Am Coll Cardiol. 2017;69(11 Suppl):1297.

https://doi.org/10.1016/j.jtcvs.2019.05.026

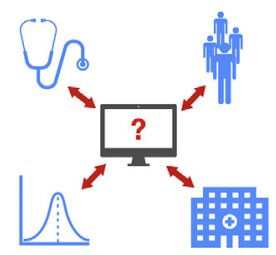

REPLY: "SENSITIVITY" AND "SPECIFICITY" REDUCTION OF BLOOD TRANSFUSION AFTER TRANSCATHETER AORTIC VALVE REPLACEMENT: IS

THAT ALL THAT MATTERS?

\section{Reply to the Editor:}

Administrative data are readily available, inexpensive, and potentially very useful sources of clinical information; however, the accuracy of these data might represent an issue. With regard to blood transfusion, the most optimistic studies reported the International Classification of Diseases, Ninth Edition procedure codes to have a sensitivity and specificity of $83 \%$ and $100 \%$, respectively; others described a 71.6\% sensitivity and $92.6 \%$ specificity. ${ }^{1,2}$

Mullan and colleagues ${ }^{3}$ properly highlighted this potential weakness of administrative database regarding the validity of the International Classification of Diseases, Ninth Edition coding for RBC transfusion and suggested a systematic undercoding of transfusion in the National Inpatients Sample (NIS) databases. We do agree with 